\title{
A pandemia e o ordinário: apontamentos sobre a afinidade entre experiência pandêmica e registros cotidianos
}

Recebido: 15.08 .20 Aprovado: 17.11 .20

\author{
Paulo Gajanigo (https://orcid.org/0000-0001-5076-8921)' \\ Departamento de Ciências Sociais, Universidade Federal Fluminense (UFF), \\ Rio de Janeiro, RJ, Brasil. \\ Rogério Souza (https://orcid.org/0000-0001-9769-1159)" \\ Instituto Universitário de Pesquisas do Rio de Janeiro, Rio de Janeiro, RJ, Brasil
}

\author{
I. Paulo Gajanigo é \\ professor adjunto \\ de sociologia no \\ Departamento \\ de Ciências \\ Sociais (COC) \\ da Universidade \\ Federal Fluminense \\ (UFF), professor \\ permanente do \\ Programa de Pós- \\ Graduação em \\ Sociologia Política \\ da Universidade \\ Estadual do Norte \\ Fluminense Darcy \\ Ribeiro (UENF) \\ e professor \\ colaborador do \\ Programa de \\ Pós-Graduação \\ em Cultura e \\ Territorialidades da \\ Universidade Federal \\ Fluminense (UFF), \\ Rio de Janeiro, Brasil. \\ <paulogajanigo@ \\ id.uff.br>. \\ II. Rogério Souza \\ é professor e \\ coordenador \\ do Programa do \\ Mestrado em \\ Sociologia Política \\ (PPGSP) do Instituto \\ Universitário de \\ Pesquisas do Rio de \\ Janeiro (luperj- \\ Ucam), coordenador \\ do Laboratório de \\ Estudos da Cidade \\ e Cultura (Lecc; \\ luperj-Ucam), Rio de \\ Janeiro, Brasil. \\ <rogeriosouza@ \\ iuperj.br>.
}

Keywords: Diary. Testimonial. Pandemic. Trauma. Everyday. 
1. I am tired of being part of a major historical event. Corona Virus Memes 2020. Disponível em: $<$ https://www. corona-virus-memes. com/corona-virusmemes/i-am-tiredof-being-a-part-ofa-major-historicalevent-meme/>. Acesso em: $30 \mathrm{Jul}$. 2020.

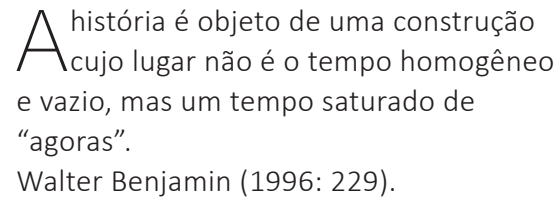

$\square$ om a decretação da pandemia do novo Corona vírus em 2020, a frase "o mundo que conhecemos não será mais o mesmo" passou a ser repetida inúmeras vezes, em diferentes meios de comunicação e por diversos atores sociais. Este enunciado trouxe consigo a ideia de uma mudança histórica para a humanidade, anunciando o fim de uma era e um mundo novo em construção. Envolto de incertezas, desconfianças, medo e pânico, esse enunciado pode ser visto como uma forma compartilhada de registro sentimental da primeira fase da pandemia, marcada pelo emprego de medidas governamentais de distanciamento social e quarentena. Essa fase, de duração ainda desconhecida quando escrevemos este artigo, se apresenta como um longo período de transição.

Nesse período, um dos inúmeros memes que se tornou viral tratava do cansaço que é viver um momento histórico ${ }^{1}$ e fez ver certa experiência curiosa: a intensidade gerada pela percepção de relevância e urgência contrastaram com certa banalidade da experiência. Apesar das metáforas recorrentes de uma guerra, a experiência da pandemia tem pontos de afastamento da experiência de um confronto bélico, não só pela recorrente imagem de um inimigo invisível, mas também por um embaraIhamento entre ação e reação. Apesar do placar diário de mortos e infectados e do índice de isolamento, tivemos que aprender a entender que as estatísticas respondem a ações realizadas duas, três semanas antes. As batalhas não estão marcadas no tempo e no espaço, elas se diluíram em todos os hábitos, a atenção exigida se voltava para uma reforma molecular em nosso cotidiano. Dessa forma, o elemento trágico da batalha se dilui formando algo mais próximo do drama.

Partimos da ideia de que uma característica bastante compartilhada na experiência da pandemia tem sido o foco nos traços desse momento histórico no cotidiano. É como se a concentração energética da anunciação de um momento histórico se espraiasse para pequenos e inúmeros afluentes. O resultado parece ter sido um impulso para o agora. Nesta pandemia, estaria se formando uma estrutura de sentimento - aquilo que Raymond Williams (1975: 47) chama de "o senso sentido da qualidade da vida em um lugar e um tempo particular" - marcada por uma atenção ao cotidiano, uma sensação de que nos encontramos, como diz a epígrafe de Benjamin (1996: 229), "em um tempo saturado de agoras". Neste artigo, exploraremos essa hipótese, identificando, na experiência da fase da pandemia marcada pelo distanciamento e isolamento social, características dessa estrutura de sentimento 
e relacionando-a com uma forma de registro da pandemia por meio de relatos, testemunhos e diários. Essa forma de registro aparece num contexto em que se busca: captar e perceber essas experiências "saturadas de agoras"; coletar e investigar a maneira que os sujeitos estão encontrando para lidar com este momento; e descrever o conjunto de experiências individuais e coletivas frente à pandemia e ao isolamento social. Tais questões vêm desencadeando inúmeras iniciativas de produção, coleta e divulgação de relatos e diários sobre a vida na pandemia - em jornais, instituições arquivísticas, grupos de pesquisa, blogs e redes sociais.

Somos parte do que pesquisamos, não apenas por que estamos imersos no contexto da pandemia, mas também porque, no mês de março de 2020, iniciamos um projeto de coleta e compartilhamento de relatos do cotidiano durante a pandemia ${ }^{2}$. As reflexões deste artigo estão fortemente marcadas pela experiência desse projeto, mas não se restringem a ela. Fazemos uso também de um mapeamento de outras iniciativas de coletas de registro e também de um panorama mais amplo e superficial da popularidade da forma relato e diário em circulação nos meios de comunicação durante esse período. Com esse material, propomos discutir e analisar a existência de afinidade entre a estética dos relatos, testemunhos e diários com a experiência específica da pandemia, na fase de isolamento social e quarentena.

De início, trataremos do levantamento das iniciativas de produção de relatos durante a pandemia, dando especial atenção às iniciativas de instituições arquivísticas e suas justificativas para se propor uma construção de memória via registros cotidianos de pessoas comuns. A partir das justificativas, exploramos como aspectos específicos da experiência pandêmica se relacionam com a atenção ao cotidiano. Em seguida, usando como base a pesquisa com nosso grupo, discutiremos relatos coletados, a fim de identificar, especulativamente, como na forma dos relatos se articula a experiência pandêmica. Por fim, trazemos a discussão sobre literaturas de testemunho - que se deu a partir do pós-segunda grande guerra com os relatos biográficos do Holocausto reverberando nos relatos e memórias das lutas anticoloniais e no processo de redemocratização na América Latina (Seligmann-Silva, 2013a) - como forma de refletir sobre as articulações entre produção e coleta de relatos em eventos traumáticos ou disruptivos e a especificidade desta experiência de pandemia.

\section{O registro da pandemia pelo ordinário}

Numa pesquisa exploratória, evidentemente no calor dos acontecimentos, identificamos dezenas de iniciativas de coleta de registros do cotidiano da pandemia por instituições arquivísticas e de pesquisa em diversos países ${ }^{3}$. No caso das instituições arquivísticas, em geral, convocam-se pessoas comuns, sem qualquer pré-requisito,
2. Grupo "Relatos do cotidiano durante a pandemia". Facebook, 2020 Disponível em: $<$ https://www. facebook.com/ groups/226156 1834146786>

3. Destacam-se os projetos da Associação por Autobiografia na França "Mémoire des confinements"; o chamado da Associação dos Historiadores do Estado de Nova York; "Coronarchiv", parceria da Universidade de Hamburgo com diversas instituições, na Alemanha;

"Recording Covid 19" do Mass Observation Project, do Reino Unido; "Memorias del confinamento", do Arquivo Municipal de Barcelona;

"Archives de

Quarantaine: dossier Covid-19", da Bélgica. No Brasil, destacam-

se as iniciativas:

"Testemunhos do isolamento" do Arquivo Geral da Cidade do Rio de Janeiro; "Documentando a Experiência a Covid-19 no Rio Grande do Sul" do Arquivo Público do estado do Rio Grande do Sul; "Arquivos da pandemia" da Casa de Oswaldo Cruz (Fiocruz); e iniciativas em universidades como Universidade Estadual de Campinas (Unicamp), Universidade Federal do Rio de Janeiro (UFRJ) e Universidade Federal Fluminense (UFF). 
para registrar e relatar a vida durante a pandemia. A valorização do registro da vida social pelas pessoas comuns não é nova. Há décadas vemos projetos voltados a esse tipo de documentação. Na experiência pioneira do Mass Observation iniciada em 1936, pessoas comuns eram convidadas a registrar o seu olhar sobre grandes eventos. Foi construída, assim, uma rede de colaboradores (não-especialistas) que alimentam permanentemente um arquivo da vida social britânica (Jeffery, 1999). Na França, há a experiência do arquivo de diários impulsionado pela Associação pela Autobiografia, criada em 1991, e que arquiva e disponibiliza à leitura diários de pessoas comuns (Lejeune, 1997). É a partir desse acúmulo que podemos ler o manifesto de arquivologistas e historiadores franceses em lançar um chamado amplo "Por uma memória ordinária do extraordinário", no mês de abril de 2020.

\begin{abstract}
Nós, historiadores, sociólogos e arquivistas, convocamos indivíduos, instituições e os poderes públicos a conservar os arquivos sobre este evento que rompe com o cotidiano das sociedades industrializadas a escala planetária. Sua análise deve lançar luz às "vidas minúsculas", geralmente invisíveis, mas que participam da grande história das sociedades humanas. [...] O desafio é, por um lado, dar voz àqueles que administram a crise no cotidiano. [...] O desafio é, enfim, contribuir para a construção de uma memória "ordinária", inclusiva e cidadã da pandemia (Piguet \& Montebello, 2020).
\end{abstract}

Este chamado sugere uma posição política no processo de coleta de materiais do cotidiano. O arquivamento, como passagem do privado ao público (Derrida, 1995: 13) de registros das "vidas minúsculas", faz emergir aquilo que não era para ser publicizado, uma pandemia contada não por gráficos e medidas governamentais, mas por pequenas narrativas. Como afirma Homi K. Bhabha (1998: 31-32), ao tratar da visão de Hannah Arendt sobre o público e o privado, esse emergir escancararia que o privado é político.

Como veremos mais à frente, a valorização do registro ordinário parece estar nas próprias raízes da modernidade, o foco sobre a pessoa comum, sem qualidades, e a descrição dos dias banais é uma tendência significativa na literatura dos séculos XIX e principalmente do XX. Evidentemente, essa atenção ao ordinário ganhou um novo impulso com as novas mídia. A tecnologia de produção e comunicação possibilitada pelo advento da internet e dos smartphones, colocou o registro do ordinário em outro patamar. O esmaecimento das fronteiras entre receptor e produtor faz o ordinário ganhar maior relevância, como destaca Ana Carolina Ecosteguy. Para a autora,

há uma evidente conjunção de forças agindo na configuração de uma dinâmica cultural própria deste tempo [...]. Esta é constituída 
por uma série de registros midiáticos que fazem parte de um movimento onde o ordinário da vida é relatado pelo próprio personagem de quem se fala, estabelecendo uma relação de contiguidade com a realidade (Ecosteguy 2009: 1).

Ao considerar essas iniciativas de registro, chama atenção que, aparentemente, não seria necessário convidar as pessoas para registrar seus cotidianos num período em que elas o fazem já como nunca se observou antes. Essas instituições poderiam coletar por marcadores (tags) do vasto material que flui nas redes sociais. Já nos primeiros dias da aplicação de medidas de quarentena, tags como \#diariodaquarentena; \#quarantinedays; \#quarantinemood; \#quarantinediaries ${ }^{4}$ se popularizaram. Frédéric Clavert, pesquisador do Luxembourg Centre for Contemporary and Digital History, em comentário sobre as iniciativas de coleta dos relatos da pandemia, apontou a ambiguidade sobre os registros digitais da pandemia.

[A pandemia] ocorre em um contexto midiático específico, das redes sociais digitais e da internet: esta epidemia pode assim tornar-se - do ponto de vista histórico e social - a epidemia mais documentada... ou ver sua memória desaparecer muito rapidamente ${ }^{5}$.

Ao insistir na produção específica de registros, essas iniciativas realçam uma distância entre o que se produz e se arquiva em escala industrial como tweets, postagens formando o big data, e um registro orientado para arquivo. Como aponta Daniela Agostinho (2016: 441), big data, por sua sensibilidade específica de registro, exclui e reduz o que é arquivado. Se para muitos, as redes sociais fizeram do diário um formato obsoleto, para as instituições arquivísticas, há algo relevante da experiência cotidiana que se perde no fluxo das postagens. Portanto, seria preciso fornecer orientações para a produção desses registros. O Royal College of Physicians of Edinburgh sugere que se mantenha um diário, evitando anotações abreviadas e registrando "o mundano assim como os grandes eventos. Não revise ou reescreva os registros após os fatos - é melhor gravar como foi no momento do que em retrospectiva" ${ }^{1}$. O mesmo tom vemos na chamada da Association of Public Historians of New York State (Aphnys):

Mantenha um diário. Começando hoje, registre suas memórias dos eventos locais e das reações ao COVID-19 ao menos desde o início de março. Continue a atualizar o diário com os avanços: o que tem feito, o que tem ouvido e visto, e como a resposta ao COVID-19 tem afetado seus hábitos normais ${ }^{7}$ ?

Outro aspecto elencado como justificativa para essas coletas está na particularidade deste evento em provocar rapidamente mudanças intensas na vida social.
4. Até o dia 5 de agosto de 2020 foram registradas na plataforma Instagram as seguintes quantidades em valores aproximados de ocorrências: \#diariodaquarentena 12,8 mil;

\#quarantinediaries 290 mil: \#quarantinedays 487 mil; \#quarantinemood 266 mil (fonte: Instagram).

5. Tradução nossa de: "Elle se déroule également dans un contexte médiatique particulier, celui des réseaux sociaux numériques et du web: cette épidémie peut ainsi devenir - du point de vue historique et social du moins l'épidémie la plus documentée... ou voir sa mémoire pâlir très vite". "Préserver la mémoire d'une épidémie". L’histoire contemporaine à l'ère numérique, 2020. Disponível em: <https:// histnum.hypotheses. org/3274\# comments>. Acesso em: 30 Jul. 2020.

6. Tradução nossa de: "the mundane as well as the large events. Don't revise or rewrite entries after the fact - it is better to record how it was in the moment rather than with hindsight". Royal College of Physicians of Edinburgh. "RCPE recording COVID-19 / coronavirus". 2020. Disponível em: <https://www.rcpe. ac.uk/heritage/rcpe- 
recording-covid-19coronavirus $>$. Acesso em 30 Jul. 2020.

7. Tradução nossa de: "Keep a diary. Beginning today, record your memories of local events and reactions to Covid-19 at least since the beginning of March. Continue to update that journal as we move forward: What are you doing, what are you hearing and seeing, and how is the response to Covid-19 affecting your normal habits?" Association of Public Historians of NYS. Historians: Start Documenting Covid-19. 29 de março de 2020. Disponível em: <http://www.aphnys. org/historiansstart-documentingcovid-19/>. Acesso em: 30 Jul. 2020.

8. Documenting a Pandemic in Real Time - A New York Minute In History. Entrevistadores: Devin Lander e Lauren Roberts. Entrevistados: Christine Ridarsky e Matthew Urtz. WAMC Podcasts, 10 Abr. 2020. Podcast. Disponível em: <https:// wamcpodcasts. org/podcast/ documenting-apandemic-in-realtime-a-new-yorkminute-in-history/>. Acesso em: $30 \mathrm{Jul}$. 2020.
O texto dos historiadores e arquivistas franceses, citado mais acima, refere-se ao conceito Marcel Mauss para tratar a pandemia como "fato social total" (Piguet \& Montebello, 2020). Considerando a pandemia como um processo que impacta todos os poros da vida social, um olhar ordinário de pessoas comuns busca responder à escala ampla e à alta densidade do fenômeno, incapaz de ser percebido com justeza apenas com histórias oficiais.

Existe ainda uma questão técnica não menos relevante. O isolamento social como medida sanitária significou também que pesquisadores não fossem a campo registrar o fenômeno em seu cotidiano. A opção por relatos pessoais e diários se configurou também como uma solução técnica para o registro, tal como argumentou Christine Ridarsky, presidente do Conselho da Aphnys ${ }^{8}$. É provável que essa tenha sido uma questão significativa para projetos de pesquisa que, ainda que não trabalhassem com autorregistros, optaram por incentivar esse tipo de material para continuarem ou efetivarem suas pesquisas.

Num contexto mais amplo, observamos iniciativas jornalísticas de publicação de relatos que sugerem um público significativo que olhou a pandemia pelos registros do cotidiano de outros. A Folha de S. Paulo, por exemplo, criou um diário coletivo, publicando relatos de um dia todos os dias, com pessoas diferentes e de localidades diversas. Em um formato parecido, o jornal Financial Times, a rede televisiva norte-americana $A B C$, a editora Companhia das Letras etc., publicaram relatos em forma de diários durante o período da pandemia. Como indicamos no início, partimos da hipótese de que a forma do registro do cotidiano, como diário, relato e testemunho, tornou-se uma forma social privilegiada para organizar a experiência pandêmica. Nesse sentido, caberia avaliar, ainda que especulativamente, que aspectos da experiência pandêmica dialogam com essa forma.

A principal medida da primeira fase do enfrentamento da pandemia - o isolamento social - fez da pandemia algo de profundo impacto geral. Talvez seja difícil encontrar um evento que articule tão intimamente os aspectos coletivo e geral. Não existiria, por isso, posição privilegiada para seu registro. A chamada "linha de frente", uma das inúmeras metáforas bélicas utilizadas, formada por profissionais da saúde em atuação nos hospitais é um dos pontos de observação, mas não chega a ser um ponto privilegiado para compreender as mudanças da dinâmica social relacionada à pandemia, nesse caso, uma descrição da vida banal, dificilmente articulada por metáforas bélicas, também oferece um acesso significativo do fenômeno.

No seu aspecto espetacular, a pandemia parece bem menos potente do que a guerra. Por mais que se evoque essas metáforas, os desenhos do inimigo, das batalhas, 
dos heroísmos exigem traços realçados. No campo imagético, a comparação com a guerra é mais difícil: as "batalhas" acontecem dentro dos hospitais, em leitos de UTI; o "inimigo" não é visível, não tem personalidade. A "guerra" parece ser evocada muito mais como uma forma de modular, uma disposição afetiva para uma disciplina coletiva de enfrentamento da pandemia - denunciando assim o déficit mobilizador da pandemia em relação à guerra. Mas tal como a guerra, pandemia é uma tragédia massiva. Mike Davis (2006: 3), escrevendo sobre a gripe aviária, identifica na ideia de megatragédia uma dificuldade comum. "Grandes epidemias, como as guerras mundiais e os períodos de escassez, massificam a morte em eventos de escala além de nossa compreensão emocional" ${ }^{\prime \prime}$. Davis aponta que para dar medida da carga emocional dessas tragédias se recorre a personificações. "A Solução Final, por exemplo, tem pouco impacto emocional profundo até que se leia $\mathrm{O}$ Diário de Anne Frank ou se veja os artefatos deploráveis no Museu do Holocausto. Então é possível chorar" ${ }^{10}$ (Davis, 2006: 3). O diário e os objetos seriam uma forma de ter acesso ao vivido obnubilado por sua generalidade. Nesse sentido, quanto maior a tragédia, mais se necessitaria coletar registros pessoais e íntimos. Este é o impulso que moveu a plataforma digital "Inumeráveis", por exemplo, dedicada a apresentar registros de parentes ou amigos de vítimas fatais da Covid-1911.

Outro aspecto comparativo é o da escala temporal. Guerra e pandemia são eventos coletivos longos, portanto, compreendem uma nova rotinização. Nesse sentido, a relação ordinário-extraordinário explorada pelos projetos de coleta de relatos e testemunhos evidencia uma tensão dos longos eventos que esticam o extraordinário até serem vividos ordinariamente. O diário, com seu ritmo, responde a esses eventos, sendo uma forma de contar os dias; e quando aparecem adjetivados, como o "diário da pandemia", servem de organizadores de uma experiência ordinária e extraordinária ao mesmo tempo. Ordinária por ser um diário, atento aos detalhes da rotina, e extraordinária pois é um diário qualificado como um tempo especial, um período específico retirado da condição de diário simplesmente. Essa foi a estratégia literária de Daniel Defoe (2014) em representar a pandemia do botulismo em Londres no século XVII por meio de um diário que remonta o fenômeno pela sucessão dos dias.

Por fim, considerando o diário como forma afeita ao registro de intimidade, como um espaço de confissões, sua relevância também está relacionada ao reposicionamento da domesticidade que o isolamento social provocou. A permanência por mais tempo em casa e a proibição de aglomerações ao se somarem ao quadro tecnológico e social contemporâneo geraram uma maior exposição da vida doméstica no espaço público. Com os smartphones, e outros dispositivos ${ }^{12}$, não só o público invadiu a privacidade - como já tinha feito o rádio, a televisão e a internet - mas o próprio
9. Tradução nossa de "Great epidemics, like world wars and famines, massify death into specieslevel events beyond our emotional comprehension".

10. Tradução nossa de: "The Final Solution, for example, has little gut impact until one reads The Diary of Anne Frank or sees the pitiful artifacts in the Holocaust Museum. Then it is possible to weep."

11. Inumeráveis, 2020. Disponível em $<$ https://inumeraveis com.br/>. Acesso em: 30 Jul. 2020.

12. Sobre o impacto das novas mídia na relação entre espaço público e privado, ver Papacharisi (2010). 
público aparece como uma conexão entre domesticidades - a partir das quais o conteúdo midiático é produzido, ou seja, a casa como estúdio de gravação. Isso pode elevar a fala íntima ainda mais à esfera pública e reimpulsionar o diário com registro público. Nesse contexto, o diário ganharia mais legitimidade como forma válida de registro da vida social, não só dentro dos estudos científicos, onde já há uma tradição relativamente longa que valoriza esse tipo de forma de escrita -, mas, principalmente, num largo âmbito social em que a leitura da intimidade do outro apareceria como leitura do próprio social.

Em nosso projeto compartilhamos das intenções observadas acima. Ao optarmos por coletar os relatos via a plataforma do Facebook, tivemos que dar atenção especial à questão da relação com as formas corriqueiras de registros cotidianos das redes sociais e relatos com fins de arquivamento. Como mencionado na introdução deste artigo, parte significativa de nossas análises partem de um projeto de pesquisa sobre relatos do cotidiano coletados durante os primeiros meses da pandemia. Para isso foi criado um grupo privado em uma rede social. O grupo "Relatos do cotidiano durante a pandemia" teve o seu início no dia 19 de março e até 22 de julho contava com 407 membros e com 117 relatos postados além de fotos, vídeos, poesias e pequenos contos referentes às experiências vividas na pandemia, totalizando até o momento 157 postagens. Seu público é majoritariamente feminino, com 71\%, e mais de $50 \%$ dos participantes têm de 25 a 44 anos de idade.

Para afastar o registro de uma postagem típica dessa plataforma, criamos um grupo privado virtual dentro da plataforma, permitimos que postagens anônimas fossem feitas e retiramos a possibilidade dos usuários comentarem as postagens. Dessa forma, afastamos dois elementos importantes da dinâmica dessa rede social virtual: polêmicas ocasionada pelos comentários - o que pode gerar um cuidado excessivo na escrita por causa do receio em ter seu relato criticado ou um foco na busca de elogios -; a viralização, já que as postagens não poderiam ser compartilhadas para

13. Essa quebra da dinâmica encontrou resistência, ao fazermos uma enquete com os participantes, a maioria expressou querer a habilitação dos comentários. fora do grupo ${ }^{13}$.

O projeto teve até o momento três atividades principais. A primeira foi a de convocação para entrada no grupo, realizada inicialmente entre estudantes do campus da UFF de Campos dos Goytacazes, depois em grupos de estudantes de outras universidades, e depois por meio de divulgações realizadas pelas universidades (UFF e Ucam) para um público mais amplo. A segunda atividade envolveu a administração do grupo, que abarcou além das aprovações e reprovações das postagens-relatos (reprovava-se anúncios ou postagens que não tinham como objetivo o registro pessoal, ou mesmo relatos que envolviam uma terceira pessoa identificável), postagens que buscavam incentivar o exercício do olhar para os detalhes do cotidiano e 
a organização dos relatos em seções que foram se ampliando à medida que recebíamos diferentes materiais (começamos com a seção Relatos, que incluía textos, fotos e vídeos que registravam esse cotidiano, depois incluímos as categorias Arte, Sonhos e Objetos (para fotografias de objetos relevantes na nova rotina). Por fim, aplicamos um questionário para os colaboradores com objetivo de: compreender e analisar as motivações que levaram a participarem do grupo como colaboradores; identificar como está sendo a experiência de postar e ler os relatos; traçar um perfil sobre os colaboradores; e receber opiniões e sugestões sobre a dinâmica do Grupo de Relatos. Esse questionário foi respondido por 28 participantes.

No decorrer do período pesquisado, ou seja, de 19 de março e até 22 de julho, o fluxo de postagem seguiu o seguinte comportamento: dos 117 relatos postados $12 \%$ foram no mês de março. Os meses de abril e maio concentraram o maior volume de postagem, $49 \%$ e $24 \%$ respectivamente. Foram nesses dois meses que as medidas de isolamento social e quarentena, em grande parte das regiões do país, foram acentuadas, acompanhadas de um aumento diário no número de novos casos de contaminação e morte causada pela Covid-19. Nos dois meses seguintes, observou-se uma diminuição significativa no número de postagens, $7 \%$ em junho e $8 \%$ em julho.

Para a análise deste artigo foram selecionados relatos, ou parte deles, da seção do grupo "Relatos" postados ao longo dos meses de março a julho e que evidenciam dinâmicas temporais da vida ordinária durante esses primeiros meses da pandemia. Utilizamos esses relatos de forma exemplar, não realizando, para este trabalho, uma análise geral dos relatos, como variações sentimentais e temáticas. A forma como foi possível convocar participantes (via redes sociais e com perfil dos coordenadores do projeto) restringiu o público a círculos sociais e geográficos bem marcados. A maioria dos participantes são das cidades do Rio de Janeiro, Campos de Goytacazes e Niterói. Ainda assim, há uma significativa presença de pessoas de São Paulo e alguns de Porto Alegre, Salvador, Vitória e Belo Horizonte além de outros países, como Portugal, Angola, Suécia, Argentina e França, em sua maioria compostas de brasileiros morando no exterior.

Ao levar esse aspecto em consideração, focamos neste artigo no uso exemplar de relatos com o objetivo de investigar especulativamente as formas de vivência do cotidiano da pandemia de sujeitos que se sentiram na necessidade de registrá-lo ${ }^{14}$. Por fim, cabe registrar que, pela análise dos relatos, seus produtores estavam em um alto grau de isolamento. Registramos apenas dez de relatos que tratavam de situações de trabalho fora de casa

14. Foi feita uma consulta aos participantes do grupo sobre a utilização e publicação dos relatos neste artigo. 


\section{Relatos e experiências na pandemia}

Iniciamos com a reprodução de um relato completo, publicado logo no começo da adoção de medidas de quarentena.

São 2 h12 por aqui, eu já não consigo separar o inconsciente do consciente, sabe quando você decide não ler sobre o covid-19, a situação global do mundo ou sobre o governo federal, mas cinco minutos depois todas as abas abertas no seu celular são sobre o assunto, mesmo sem querer?! Todas as redes sociais falam sobre o tema, a cada minuto uma atualização, meio surreal tudo. É madrugada de domingo, meu nono dia de quarentena, eu sempre quis mais tempo de férias pra colocar tudo em ordem, mas agora, só consigo consumir notícias de caos, irresponsabilidade, medo e morte. Quando deitei, achando que ia dormir, esquecer, nessa hora Lênin, meu gato, entediado por ele, por mim e por minha companheira não parava de miar. Assim, como eu, ele só queria sair, e eu só queria respirar um pouco sem muitas preocupações. É nesse momento que me dou conta de uma música, uns funks que ecoavam pela minha janela, umas vozes. Era o meu nono dia e eu ainda ouvia vida na rua. Pessoas se divertiam e mesmo sem estar lá, eu as via dançar. Eu instintivamente pensei muitas vezes ao longo da madrugada em descer os quatro ou cinco lances de escada da vila para acompanhar de perto a festa que os vizinhos vaziam na rua para celebrar a vida, ou talvez, o dia difícil de trabaIho, para mim, de alguma forma as risadas, as músicas que vinham da rua, soavam como um desafio ao caos, ao vírus e a doença. No entanto, ando paralisada demais para desafiar a quarentena - me sinto assustada em ter que ir colocar o lixo pra fora -, mantenho diferentemente deles uma sociabilidade reclusa que concluiu que o melhor agora é o autoisolamento.

\section{One minute}

\section{One minute}

É... É que acho melhor ir dormir agora, isso... vou dormir tentando entender nossas decisões diferentes de sociabilidade nesse

15. Uns dos primeiros relatos enviados para o grupo "Relatos do cotidiano durante a pandemia", 26 de março de 2020

16. A noção de estar experimentando um momento histórico, único, não vivido até agora, é sensível nos relatos postados. cenário. Eu até poderia de forma presunçosa dizer que talvez nem saibam sobre o corona vírus ou ainda especular que como o presidente do Brasil, meus vizinhos também consideram a pandemia do corona vírus uma "gripezinha", talvez... Mas agora, eu vou dormir e só tenho, só tenho uma certeza, a que já sinto falta do trabalho de campo ${ }^{15}$.

Ao testemunhar, narrar e registrar as experiências do momento histórico ${ }^{16}$ da pandemia, há o sentido de sobrevivência em um ambiente que foge à normalidade, como demonstra o relato acima, no ato de preservar e compartilhar essas experiências, 
por meio de relatos que se objetivam como diários. A estrutura do diário traz a estética da presentificação dos atos do autor-protagonista que se misturam às tramas do seu dia a dia, entre a vida particular e vida pública. O diário, como bem salienta Seligmann-Silva (2009), traz um ritmo, um clima, como se a própria respiração do autor-protagonista pudesse ser sentida pelo leitor, como fica marcado na repetição da expressão "one minute" no relato acima, traz também os erros gráficos, os lapsos e discordâncias textuais caracterizando o "teor testemunhal"17 em um "estado de acontecer" reforçando a ideia da presentificação fundindo autor-protagonista, "texto e temporalidade" performativamente ${ }^{18}$ (Seligmann-Silva, 2009: 161-162).

Dizem que ser carioca é comer biscoito o Globo, beber Mate gelado com limão e praticar nos parques e areias da cidade do maravilhosa o famoso altinho. Hoje, 22 de março de 2020, ser carioca não significa estar na praia. Ser carioca neste momento é pensar no todo, entender que sozinho não podemos encontrar o carinha do Mate ou jogar aquela bolinha. Hoje no primeiro fim de semana oficial de quarentena no Rio de Janeiro a famosa praia de Copacabana estava completamente vazia. Um enorme vazio que trazia consigo um silêncio aparentemente composto por medo e também esperança, era o carioca entendendo que nesse momento o "brotar" seria cada um em sua própria casa para o bem de todos. Em quase trinta anos é a primeira vez que encontro a praia assim em um dia de sol, embora trinta anos pareçam poucos, quando puxo em minhas memórias os momentos de praia essa é a primeira vez que presencio algo assim ${ }^{19}$.

Não sei mais em qual dia de isolamento estamos. Tem sido dias difíceis e confusos pela falta de rotina. Alguns vizinhos mantêm um churrasco há uns quatro dias, respeitando a lei do silêncio em partes, pois os decibéis alcançados nas conversas atrapalham tal qual uma música alta. As crianças da rua soltam pipa e jogam bola como se estivessem em férias. Nas primeiras semanas o isolamento era totalmente respeitado no bairro (me refiro sobre as quadras ao redor da minha casa, onde consigo observar) mas com o passar das semanas e a enxurrada de desinformação que estamos recebendo, afrouxaram o protocolo. Me parece que essas coisas deslegitimaram a ordem de isolamento. Dentro de casa, meus pais idosos tentam manter a calma ocupando-se o máximo que podem. Eles pensavam que o isolamento duraria até o final do mês de março e após, tudo voltaria o normal; porém, com suas expectativas frustradas, a ansiedade e a desesperança só aumentam. Já relativizam o contágio com o Covid-19; dizem preferir isso ao enlouquecimento do isolamento vertical. Dias difíceis. Já nem sei o que pensar...20
17. Os diários tratam do ordinário e do cotidiano de diversas situações e experiências vividas pelo autor-protagonista enquanto o testemunho carrega o caráter da denúncia, da urgência e da ruptura com o silêncio. O diário é um marcador e registro da experiência, o testemunho é uma denúncia da experiência.

18. O escritorprotagonista, ao selecionar o que vai relatar como experiência íntima de seu universo cotidiano, vai de palavras a imagens, de imagens a palavras, misturando e embaralhando passado-presentefuturo. Assim, sua escrita desempenha essa relação temporal e simbólica que está à mercê de sua experiência.

19. Relato postado em 22 de março de 2020.

20. Relato postado em 26 de março de 2020. formado por um emaranhado de notícias sobre a pandemia, de sons dos vizinhos, 
sentimentos de medo, precauções, do olhar contemplativo voltado à praia em um misto de "medo e esperança", ou seja, mesmo se esta realidade da vida cotidiana é constituída de "agoras" do presente imediato, isso não impede que fenômenos distantes do "aqui e agora" venham a se entrelaçar às experiências ordinárias, levando a experimentação da vida cotidiana a diferentes graus de presença e distanciamento, como apontados por Berger e Luckmann (2012):

\begin{abstract}
A realidade da vida cotidiana está organizada em torno do "aqui" de meu corpo e do "agora" do meu presente. Este "aqui e agora" é foco de minha atenção à realidade da vida cotidiana. Aquilo que é "aqui e agora" apresentado a mim na vida cotidiana é o realissimum de minha consciência. A realidade da vida diária, porém, não se esgota nessas presenças imediatas, mas abraça fenômenos que não estão presentes "aqui e agora". Isto quer dizer que experimento a vida cotidiana em diferentes graus de aproximação e distância, espacial e temporalmente (Berger e Luckmann, 2012: 38-39).
\end{abstract}

21. David Lapoujade (2017: 89-90) discute esses dois conceitos "atenção à vida" e "apego à vida", desenvolvidos na obra filosófica de Henri Bergson. Para efeito de emprego neste artigo, utilizamos "atenção à vida" e "apego à vida" ambos como sendo mecanismos que possibilitam os sujeitos se adaptarem às exigências do mundo real no qual estão inseridos.
Será nesse movimento entrelaçado entre presença e distanciamento, da experiência íntima do eu e dos fenômenos sociais externos, que os relatos da vida cotidiana enquanto experiência irão constituir uma forma estética para o evento-histórico da pandemia. Uma estética que vigora tanto na "atenção à vida" quanto no "apego à vida" 21 e que, mesmo diante de enunciados calamitosos que pautam expressivamente o nosso cotidiano, há, nos relatos, narrativas que apontam para expectativas por possibilidades vindouras.

A presentificação, ou seja, a expressividade que o sentido do agora tem nos relatos da vida cotidiana, é uma das marcas que caracteriza os diários e as escrituras do eu, como bem observou Seligmann-Silva (2009). O autor enfatiza que, no diário, o autor-protagonista vive numa forma de presente absoluto, num estado de presentificação constante. No entanto, como também destacado pelo autor, essa presentificação que pressupõe a estrutura de um diário é atravessado por estruturas temporais distintas embaralhando as narrativas do autor-protagonista e criando justaposições ambientais entre o que está acontecendo no interior da vida e da experiência íntima com o que se passa no mundo exterior no qual o autor-protagonista está inserido. Nos relatos postados em nosso grupo percebe-se, de inúmeras formas, esses atravessamentos, ligando experiências íntimas experimentadas pelo autor-protagonista às experiências coletiva, social, pública em geral.

Quase duas horas para guardar as compras, passamos álcool em gel em cada pacote de biscoito, cada pacote de feijão e macarrão, tiramos do saco as carnes, separamos em porções, lavamos as cai- 
xas de leite, as latas de milho verde, cansativo demais, foram as compras do mês, nada apocalíptico para durar três meses, apenas as compras do mês, e, ainda que antes já tivéssemos o cuidado de higienizar frutas e verduras, passar álcool em gel no pacote de gelatina me causou muita estranheza, lembrei da minha mãe que sempre me fala que criança tem que brincar com poeira, colocar o pé no chão e a mão na boca para criar imunidade, então fiquei pensando quanto tempo leva para que tanta higienização cause alguma diferença no nosso sistema imunológico.

Quero fugir das informações sobre a pandemia para pensar em outra coisa, ao mesmo tempo quero informação, ou seja, não consigo fugir, o Twitter e o Instagram são os aplicativos que mais acesso porque são os que mais me identifico, neles me informo, assisto "lives", rio dos "memes" e piadas, mas me irrito mais que qualquer outra coisa, com as incansáveis brigas polarizadas entre esquerda e direita onde bom senso e conhecimento cientifico são totalmente negligenciados. Meus sentimentos transitam entre insegurança e irritação em uma intensidade maior que o de costume, e, me sinto à vontade para atribuir essa intensidade ao distanciamento social. Querer ficar em casa e ter que ficar em casa viram "chaves emocionais" diferentes para mim, e estou começando a sentir falta de algumas coisas que as videochamadas e a criatividade amenizam, mas não substituem ${ }^{22}$.

Sinto que o Brasil me adoece.

22. Relato postado em 28 de março de 2020.

São 3h56 da manhã, deitei 00h30 e estou de pé fazendo as contas do saldo que tenho disponível e do quanto preciso arrecadar, por meio dos freelas, até o próximo dia 5.

Uma das abas abertas é uma pesquisa sobre a terceira parcela do auxílio emergencial que ainda não tem uma data fixada.

Penso nos meus pais, ambos incríveis em seus ofícios, sempre me inspiraram a ter garra.

Ele é Pedreiro, um dos melhores que conheço, profissão que me foi apresentada como "humilde" já que pra ser peão não precisa nem saber ler. Ele, analfabeto funcional, de fato não o sabe.

Ela é Cozinheira, uma das melhores que conheço, mesma história da profissão humilde, só que um pouco mais valorizada. Lembro de ser chamada de "filha da cozinheira" durante boa parte da minha vida e não ver maldade naquilo. Ora, eu sou filha da pessoa que estava proporcionando um momento incrível de felicidade pra várias pessoas, por que isso seria ruim?

Em 2020, mesmo após a demissão por conta da pandemia, mantenho meu aluguel em um bairro no centro da cidade e ajudo com as contas da família.

Paisinho de bosta! 
23. Relato postado em 23 de junho de 2020.

24. Termo/gíria utilizado para designar trabalho temporário.
Acabei de receber uma mensagem sobre demissão em massa em uma das universidades privadas sediada em São Paulo.

Não são só os pedreiros e cozinheiras que são tratados feito nada. Retorno aos meus cálculos, fazia algumas que não chorava ${ }^{23}$.

Nos dois relatos acima, que foram postados em momentos distintos do período da pandemia, podemos perceber que os ambientes circunscritos à vida íntima, ao ordinário e ao cotidiano são atravessados pelos acontecimentos públicos misturando-se ao agora do autor-protagonista os "agoras" dos acontecimentos sociais. Há, como bem discorre Seligmann-Silva (2009), uma trama que mistura vida íntima e vida pública, o ordeiro das rotinas diárias aos acontecimentos externos da sociedade, aproximando temporalidades e transformando, na forma de relato, um único grande acontecimento. O evento-histórico da pandemia está presente e conecta-se às experiências de cada autor-protagonista tanto no agora como também nas reminiscências, acionando lembranças de experiências distantes, mas que se misturam aos sentimentos do presente imediato.

Temos, no primeiro relato, a angustiante rotina da limpeza das compras do mercado diante das exigências sanitárias que a pandemia incutiu ao cotidiano. Ao relatar esse ato ordeiro, o autor-protagonista aciona instâncias temporais distintas, como as lembranças do tempo de criança e os cuidados que a mãe tinha com a higiene. Tudo isso se mistura entre a decisão de ficar informado ou fugir das informações sobre a pandemia e o país. Sentimentos de irritação e insegurança se misturam às noções de cuidado com a contaminação do vírus, do isolamento social e a sensação de que coisas estão faltando, bem como o que o cotidiano mudado pela pandemia e pelo isolamento social não está dando conta de substituir.

No segundo relato, o autor-protagonista anuncia já na sua primeira frase o drama que entrelaça sua vida íntima e a vida do país. "Sinto que o Brasil me adoece". O país metaforicamente assume o lugar do vírus da pandemia e o autor infectado, vai adoecendo, assim como o país também adoece. As questões sociais do desemprego e a diminuição drástica da renda de grande parte da sociedade acompanham o tom do relato como espécies de sintomas do adoecimento trazidos pelo vírus "Brasil". As contas a pagar, à espera do auxílio emergencial do governo, os "freelas" 24 se entrelaçam no agora do autor-protagonista, em memórias que evocam lembranças dos pais, seus ofícios e do orgulho que sente. As lembranças the trazem forças para encarar o cenário presente de demissões e perda de empregos no país, mas não são o suficiente para lhe poupar da tristeza. O agora pandêmico está na própria metáfora que registra a presença como signo organizador, que dá unidade ao narrado, de onde o autor coleta o vocabulário. 
O conjunto de postagens-relato em nossa pesquisa também sugere a sensação de embaralhamento do agora com o pretérito e o futuro próximo. Como indicamos acima, a pandemia é um evento cotidiano, isso significa que, para além do truísmo de que se viva esse evento no cotidiano, a forma como é vivida se relaciona com uma hipertrofia do cotidiano. Ou seja, vive-se contando os dias, como dias ordinários. Um dos aspectos que ajuda a configuração dessa forma de experiência está na dificuldade em se marcar outros ritmos que não sejam os ritmos diários. Finais de semanas ou feriados, marcadores de ritmos públicos ${ }^{25}$ mais longos como semanas ou época do ano, se esmaecem. O domingo de Páscoa foi assim descrito por dois participantes de nosso grupo:

Para pensar o que fazer para que esse domingo de páscoa não ficasse esquecido nesses dias que parecem tão iguais usei como referência o que comumente fazemos quando é páscoa o almoço em família, mas percebi que nesse domingo apenas abri um parêntese no dia e coloquei ali a páscoa, como se eu tivesse feito um esforço para sentir esse clima de páscoa, que, no entanto, no fundo, estava faltando tanta coisa e que tanta coisa estava ocupando o espaço de comemoração, que foi difícil sentir a alegria da ressurreição. Está sendo inevitável não sentir angústia, medo e insegurança, ser pessimista, quando vejo a maneira que a pandemia está sendo conduzida em nosso país. É difícil não me informar, para mim dá ansiedade ficar sem informação ao mesmo tempo em que não ajuda me informar, fico em uma corda bamba. Mas é viver um dia de cada vez e hoje eu vivi o domingo de páscoa, com direito a um almoço diferente com minha filha que eu tanto amo e que está passando por isso cem por cento ao meu lado ${ }^{26}$.

Não fizemos nada na sexta, sequer lembramos. Nada no sábado. Nada no domingo, que particularmente, foi um dia de muito estresse.

Tentei acalmar os ânimos, fiz questão do almoço na mesa e puxei uma oração.

À noite, somente após mensagens no grupo da igreja, minha mãe decidiu que era páscoa. Me interrompeu no trabalho que estava desenvolvendo e impôs nossa participação no culto que seria transmitido e na Santa Ceia ${ }^{27}$.

A existência do marcador "Páscoa" aparece como um esforço individual e não como um dado automatizado da rotina. A metáfora do "parêntese", no primeiro relato, registra o esforço individual e a compreensão da rotina como um som monótono, constante e irritante de difícil alívio - e o fim natural desses pequenos momentos.

"Hoje já estou a nem sei quantos dias em quarentena, já perdi as contas. Me perco nos dias da semana e do mês" ${ }^{28}$. Este trecho, de um dos relatos, apresenta uma
25. Henri Lefebvre (2004: 18) chama de ritmos públicos calendários, festas, cerimônias e celebrações.

26. Relato postado em 17 de abril de 2020.

27. Relato postado em 14 de abril de 2020.

28. Relato postado em 25 de abril de 2020. 
29. Evidentemente essas produções literárias não ficcionais em formato de relatos como as correspondências e os fragmentos, os manuscritos e diários não concorriam diretamente com o romance, tanto no sentido mercantil quanto no sentido da estética de uma época. O romance, segundo Georg Lukács (2007), será a expressão da modernidade e símbolo da burguesa. Ver Duarte (2011); Compagno (2014).

30. Ver Benedict Anderson (2008) em Comunidades imaginadas. 0 autor destaca a importância para a formação do ideário nacionalista europeu, o papel da impressa (jornais e folhetins) e do romance como símbolos da nação moderna a partir do século XVIII (Anderson, 2008: 65-83). Michael de Certeau(1998), aponta para as "práticas escriturísticas" como uma mistificação do fazer histórico em seu processo de dominação simbólica de um tipo único de cultura. A escritura assumirá, enquanto prática, o lugar discursivo da unificação de práticas heterogêneas da sociedade(Certeau, 1998: 224).

31. Segundo Artières (1998: 16-17), foi a partir de 1915 que W. Thomas e R. Park introduziram caraterística que perpassa boa parte dos relatos postados, uma hipertrofia do ritmo diário que vem produzindo efeitos vertiginosos, ou seja, nessa hipertrofia do cotidiano, sabemos sempre que horas são, mas nunca que dia é hoje.

\section{Os relatos da pandemia e a literatura de testemunho}

Os relatos individuais, diários e autobiografias, como já apontado, é uma das marcas da modernidade e, desde o final do século XVIII e início do século XIX, na Europa, passou a despertar, como produção social, um interesse estético e mercantil. A atenção de parte do campo editorial e literário se voltou para essa modalidade de narrativa, pautada mais pela experiência vivida pelo autor do relato do que pelo personagem ficcional, provindo da imaginação criativa de um escritor. Esse processo de escrever sobre si mesmo ou da própria experiência vem a reboque do movimento de ampliação da escrita pessoal nos meios aristocráticos, por conseguinte, de sua popularização para as camadas médias das sociedades. Durante boa parte do século XIX, fragmentos da escrita como manuscritos, diários, cartas que relatavam o ordinário e o cotidiano passaram a ser considerados com valor literários, produzidos e comercializados como tal ${ }^{29}$. Philippe Artières (1998: 13) vê nesse processo a constituição de uma sociedade onde se inscrever passa pela ordem do cotidiano. "Para existir, é preciso inscrever-se, inscrever-se nos registros civis, nas fichas médicas, escolares, bancárias" 30 .

Do século XIX em diante, tudo passará pelo escrito e a escritura estará na ordem do progresso, deixando a oralidade alhures presa nas tradições, como bem escreveu Benjamim (1996). A escrita do eu, o ato de enunciar a si mesmo enquanto experiência pessoal, subjetiva, será, principalmente a partir das primeiras décadas do século XX, objeto de interesse do campo da crítica literária, nas quais as autobiografias, correspondências, diários e manuscritos serão pensados a partir de um gênero, ou seja, uma estética literária que fará da experiência da vida ordinária parte da produção social e expressividade de uma época. O interesse pelos relatos da vida cotidiana e suas injunções sociais se estenderam também às pesquisas e aos trabalhos de história oral e da memória coletiva, como as dos sociólogos da primeira geração da Escola de Chicago, que incentivavam o uso de autobiografias e histórias de família (Artières, 1998: 16-18) 11. $^{31}$

O interesse por essa forma literária da escrita do eu se manteve e se ampliou após as duas guerras mundiais. Verificou-se um aumento significativo da produção acadêmica e literária, constituindo um campo de investigação abrangente, principalmente em decorrência do saldo traumático deixado pela experiência das duas 
guerras. No âmbito dos estudos históricos, a história oral lançou mão dos relatos e testemunhos entendendo-os como a história do tempo presente ${ }^{32}$, chamando atenção para a importância que as fontes orais e os testemunhos oculares passaram a ter para aos estudos de história contemporânea. Outros campos de pesquisa das humanidades também atribuíram importância aos relatos e testemunhos como os de memória cultural, estudos literários, sociologia da cultura e do cotidiano ${ }^{33}$ entre outros.

É mister destacar que os relatos do cotidiano, diários e autobiografias acompanharam, em certa medida, o crescimento, nos anos subsequentes à Segunda Guerra Mundial, observado da "literatura de testemunho" - forma literária pela qual sobreviventes narram em primeira pessoa as agruras dos campos de concentração e dos crimes cometidos pelo aparelho estatal. O Holocausto vai ocupar, enquanto significante, o centro das narrativas testemunhais onde gravitavam inúmeras outras experiências, como a do gulag, dos campos de concentração e os extermínios étnicos no continente europeu, das mortes e torturas causadas pela ação direta do aparelho de estado nas ditaduras latino-americanas. A ampliação da literatura de testemunho acompanhou o processo identificado por Jeffrey Alexander (2016) de generalização da experiência do Holocausto como um trauma cultural. Mais do que uma particularidade vivenciada por um povo, o Holocausto foi aos poucos se configurando como trauma cultural, marca coletiva que produziu uma gramática usada na expressão de outros sofrimentos citados acima.

Em geral, as obras trazidas pela literatura de testemunho tematizaram o "evento-limite" da experiência humana ao problematizar "os limites da representação" de um evento traumático (Seligmann-Silva, 2013b). A literatura de testemunho, segundo o autor, é de difícil classificação literária pois abarca a problemática da representação em relação a experiência-real. A literatura de testemunho se contrapõe aos efeitos irônicos, ficcionais e metafóricos do romance, seja realista ou naturalista, tratando-se de uma literatura do "real" 34 .

[...] esse "real" não deve ser confundido com realidade tal como ela era pensada e pressuposta pelo romance realista e naturalista: o "real" que nos interessa aqui deve ser compreendido na chave freudiana do trauma, de um evento que justamente resiste à representação (Seligmann-Silva: 373c, grifo do autor).

Os relatos autobiográficos compreendidos na literatura de testemunho trataram de vítimas da violência do Estado, sobreviventes de traumas históricos que trouxeram à tona histórias ocultas ou, como denomina Michael Pollak (1989), "subterrâneas". O cotidiano dessas testemunhas da história, suas lutas, fadigas, perdas, superações no Departamento de Sociologia da Universidade de Chicago a autobiografia como método de ensino.

32. Ver Ferreira e Amado (2011).

33. Ver Raymond Williams (2011) sobre a sociologia da cultura e Peter L. Berger e Thomas Luckmann (2012), sobre sociologia do cotidiano.

34. Para Seligmann Silva, a literatura de testemunho é "antimimética e antiirônica" pois se inscreve em um real que, como autor salienta acima, "resiste à representação. Por ser eventos-limite narrados por seus protagonistas, cria-se uma modalidade de recepção nos seus leitores de empatia desestimulando a incredulidade. (Seligmann-Silva: 375b). 
35. Esse programa coletou registros da vida posteriores aos atentados, buscando mapear os seus efeitos na vida da comunidade. Esse formato de arquivos "se tornou mais comum na sequência do 11 de Setembro, no Estados Unidos, quando motivou a criação do September 11th Digital Archive, iniciativa de grandes dimensões dedicada à coleta e à preservação das memórias de indivíduos comuns daqueles acontecimentos, além de dezenas de outras iniciativas menores" (Kisil, Silveira \& Nicodemo, 2020: 94-95). e traumas ajudaram a rever e repensar o passado na busca por justiças no presente, pois, como salienta Jacques Rancière (2014: 58), "[e]screver a história e escrever histórias pertencem a um mesmo regime de verdade".

A literatura de testemunho caminha para uma história contada a "contrapelo" (Benjamin, 1996), colocando no centro da análise a vida e os relatos daqueles que experimentaram o evento-limite. O trauma associa a experiência do autor-protagonista ao real, um real que "resiste à simbolização", mas que na autobiografia de testemunho opera como ferida que insiste em permanecer aberta.

A experiência traumática é, para Freud, aquela que não pode ser totalmente assimilada enquanto ocorre. [...] Evidentemente, na medida em que tratamos da literatura de testemunho escrita a partir de Auschwitz, a questão do trauma assume uma dimensão e uma intensidade inaudita. Ao pensarmos nessa literatura, redimensionamos a relação entre a linguagem e o real (Seligmann-Silva, 2013b: 48-49).

Por isso que o testemunho do autor-protagonista é mais do que a voz de um sobrevivente, de alguém que escapou do evento-limite. É como classifica Seligmann-Silva (2013: 383c), "o enfrentamento, por assim dizer jurídico com o real e reivindicação da verdade".

Um dos projetos de coleta de testemunhos e relatos da pandemia na França afirma que se inspirou no programa 13-november, uma iniciativa transdisciplinar de acompanhamento dos impactos da experiência dos atentados de 13 de novembro de 2015 e dos eventos de 18 de novembro em Saint-Denis ${ }^{35}$. Essa inspiração nos levanta questões sobre trauma e evento-limite da pandemia. Como já observado acima, as metáforas que vêm sendo amplamente utilizadas por grande parte da mídia nacional e internacional, poder público, entidades de saúde e científicas de que atravessamos um período de "guerra contra um inimigo invisível", de "mudança de paradigma", poderiam nos levar a pensar em uma experiência cotidiana relacionada ao evento-limite tal como apresentado na literatura de testemunho. Porém, esse caminho analítico e conceitual deve ser matizado para compreendermos os sentidos expressos nos relatos colhidos, por exemplo, por meio de nosso grupo de relato, considerando que o evento-limite tratado na literatura de testemunho, como bem destacou Seligmann-Silva (2013a), está diretamente relacionado ao trauma, e seu tratamento na escrita exige do autor-protagonista um distanciamento temporal. Isso não quer dizer que a pandemia não se configura como um evento-limite, mas no que se refere ao processo de registro e coleta de relatos, há 
uma concomitância entre evento-limite e registro que nos obriga a ter cautela na compreensão desses relatos no campo da literatura de testemunhos. Para esta, a depuração da experiência extrema e sua objetivação em um formato de relato necessitaria do pesado trabalho de luto ${ }^{36}$.

Foi possível perceber, em algumas iniciativas de coletas de relatos sobre a pandemia, principalmente as de cunho arquivista, uma expectativa de trauma. Os relatos são concebidos como testemunhos daqueles que anunciam e enunciam uma experiência traumática futura. Ou seja, há por parte desses projetos de coleta de relatos um sentimento de expectativa em que as experiências sociais da pandemia vividas no agora venham, num futuro bem próximo - a vida após a pandemia - ser um trauma cultural da humanidade. A urgência de coletar e arquivar configuraria uma ação "pré-traumática" (Dionísio, 2020). O timing arquivístico de antecipação se encontra com a própria sensação compartilhada de apreensão descrita por Gustavo Dionísio.
36. Ver Sigmund Freud (2016: 100101).

37. Se tomarmos a diferenciação que Freud faz entre o trabalho do luto e a melancolia, podemos pensar que a situação de um "luto sem objeto" se assemelha à identificação do eu como o próprio objeto perdido na melancolia (Freud, 2011: 71).

Diferentemente de uma catástrofe, na qual a situação traumática se coloca de pronto, o enfrentamento da Covid-19 deixa o trauma circunstanciado à indefinição, em suspenso, ou seja, "chega e não chega" - gerando assim um impasse de significativa complexidade, uma vez que esse estado iminente para que o traumático advenha já é, por si mesmo, traumático. As imagens de Manaus e do cemitério da Vila Formosa, em São Paulo, são altamente representativas da conjuntura: covas abertas às pressas à espera dos mortos (Dionísio, 2020).

Para Dionísio, a pandemia reposiciona também o luto, que sofreria uma dupla violação pela impossibilidade de ritualizar a morte e pela dificuldade de afastar-se dela, já que a ameaça viral é onipresente. Poderíamos acrescentar que, tal como há expectativa de trauma, há também expectativa de luto. Esse pré-luto não necessariamente se vincularia a um objeto específico, ou seja, não é a antecipação da perda de um parente ou amigo. A ameaça pandêmica é difusa. Esse luto por antecipação se aproximaria de uma melancolia ${ }^{37}$ - já que esta não tem um objeto de endereçamento. Mas, ainda que seja difusa, a pandemia é algo externo e pode ser mais ou menos delimitada. O pré-luto então permite tanto uma melancolia generalizada como um inventário do que estamos perdendo, a rotina, o emprego, os encontros com familiares, com os amigos, o lazer etc., como diz Julian Fuks:

A pandemia que se faz trauma coletivo, o medo difundido, a dor à espreita, tudo isso nos desorienta e acaba nos convidando a ordenar afetos, ternuras, tristezas - e assim a descobrir saudades imprevistas, a lamentar perdas antes insuspeitas (Fuks, 2020). 
38. Tradução nossa de: "Sometimes the impact of sexual trauma doesn't seem to measure up to that of collectively experienced historical events, such as war and genocide. Sometimes it seems invisible because it is confined to the domestic or private sphere. Sometimes it doesn't appear sufficiently catastrophic because it doesn't produce dead bodies or even, necessarily, damaged ones".
Dessa forma, tanto o pré-luto quanto o pré-trauma podem ser entendidos como formas de luto e trauma. Não tão similares às formas das catástrofes, mas mais próximo daquilo que Ann Cvetkovich propõe para compreender experiências e sofrimentos de um trauma sexual.

Às vezes, o impacto do trauma sexual não parece corresponder aos eventos históricos vivenciados coletivamente, tal como guerra e genocídio. Às vezes, parece invisível porque está confinado à esfera doméstica ou privada. Às vezes não parece suficientemente catastrófico, porque não produz corpos mortos ou mesmo, necessariamente, feridos (Cvetkovich, 2003: 3) ${ }^{38}$.

Diferentemente do trauma sexual, o trauma da pandemia é notoriamente coletivo. No entanto, tal como aquele, o trauma da pandemia (como pré-trauma) produz uma ida à intimidade, às relações pessoais, aos detalhes da esfera privada. Aí pode estar a comunicação sentimental entre os projetos de coleta de testemunhos, diários sobre e na pandemia e as formas de sentir dos produtores desses registros. Caberia então questionar como se compõe essa comunicação sentimental, ou seja, de que modo se articula as políticas institucionais para a produção de arquivos públicos e coletivos e esse impulso pelo arquivamento por parte das "pessoas comuns". De que modo um acúmulo institucional em torno da ideia de testemunho recebe um retorno positivo de pessoas comuns, dispostas a registrar o que estão vivendo?

Como forma de contribuir para essa questão, apresentamos uma amostra das respostas do questionário que aplicamos aos participantes de nosso grupo, na terceira etapa da pesquisa, para a seguinte pergunta: "Caso tenha escrito relatos, em que sentido essa prática te afetou?" A resposta mais comum envolveu relacionar a prática da produção do relato como o objetivo de organizar "pensamentos e percepções sobre o meio", ou, como diz outro participante: "Colocar para fora" o que vai nos entupindo... Ajuda a sistematizar essa nova realidade que nos foi "atirada nos peitos" sem que tivéssemos nenhuma preparação. Percebe-se também uma reação a um sentimento de solidão da experiência da pandemia. "Foi uma sensação de quebrar o silêncio. Aqui em casa cada um tem lidado com as suas questões e as vezes conversamos bem pouco. Ao escrever um relato pude contar pra alguém como estava me sentindo". Nesses casos, a prática de produção dos relatos teria funcionado para os sujeitos como resposta ao caráter disruptivo da pandemia, isso fica expresso sinteticamente em outra resposta: "São muitas mudanças de rotina, escrever os relatos me permite entender melhor os processos de mudança que estou vivendo". 
A partir dessa experiência de pesquisa, sugere-se que a comunicação positiva entre coleta e produção de relatos pode ser localizada na demanda de produção de significados de uma experiência disruptiva. Nesse sentido, a noção de trauma, que a literatura de testemunho traz, pode ajudar a compreender essas experiências, não somente aquilo que se refere às formulações dos projetos institucionais, mas também o impulso ao registro pelos sujeitos desses relatos.

\section{Considerações finais}

Este artigo partiu da ideia de que a experiência da pandemia vem suscitando inúmeras iniciativas de coleta de relatos do cotidiano, dentre elas a de nossa pesquisa. Tais iniciativas são impulsionadas por diversas ações de diferentes atores sociais como instituições arquivistas, pela imprensa e a mídias em geral e chegando até aos pesquisadores e cientistas sociais. Em todas, há um apreço pela captação e apreensão do agora, do cotidiano e do ordinário da pandemia. O artigo buscou apresentar e problematizar algumas das principais iniciativas de coleta de relatos sobre o cotidiano chamando atenção para o caráter da excepcionalidade e da presentificação que marcam os registros e relatos sobre o evento-histórico da pandemia. Os elementos simbólicos acionados nos diversos enunciados dão o tom da dramaticidade do momento. A "guerra" contra vírus, o "inimigo invisível" "o novo normal" e "o mundo como conhecemos não será mais o mesmo", são compartilhados pela grande mídia atravessando o cotidiano e a vida ordinária e, nesse sentido, reorganizando as rotinas e os hábitos ordinários às questões globais de saúde pública, economia e política governamental. Captar, registrar, arquivar e compartilhar essas experiências vem se tornando um meio de antecipação de uma experiência traumática.

Uma das coisas que apreendemos dos estudos sobre memória é que as formas de lembrança de um período ou evento não estão desconectadas da própria forma como os vivemos e como produzimos indícios para lembrança, como os registramos. Tal como uma geração relembra sua infância com tons sépia e cheiro de mofo das fotos amontoadas em caixas, nossas lembranças da pandemia estarão contaminadas com a forma como a estamos registrando. Uma das formas de contar esses dias será lembrando que contávamos os dias. Longe de propor que os registros coletivos sejam consequência direta da forma como a vivemos, o que propomos aqui é ressaltar a conexão positiva, a afinidade entre uma estrutura de sentimento, ou seja, uma forma de experiência da pandemia com um certo estado institucional, um paradigma sobre a importância dos registros testemunhais dos grandes eventos para instituições de memória. 


\section{Referências}

AGOSTINHO, Daniela. Big data, time and the archive. Symplokē, v. 24, n.1, 2016.

ALEXANDER, Jeffrey. Trauma cultural, moralidad y solidaridad. La construcción social del Holocausto y otros asesinatos en masa. Revista Mexicana de Ciencias Políticas y Sociales. Nueva Época. Año LXI, n. 228, p. 191-210, Set./Dez. 2016.

ANDERSON, Benedict. Comunidades imaginadas. São Paulo: Companhia das Letras, 2008.

ARTIÈRES, Philippe. Arquivar a própria vida. Revista Estudos Históricos, v. 11, n. 21, p. 9-34, 1998.

BENJAMIN, Walter. Obras escolhidas: Magia e técnica, arte e política. São Paulo: Brasiliense, 1996.

BERGER, Peter; LUCKMANN, Thomas. A construção social da realidade. Petrópolis, RJ: Vozes, 2012.

BHABHA, Homi K. O local da cultura. Belo Horizonte: Editora UFMG, 1998.

CERTEAU, Michael de. A invenção do cotidiano: arte de fazer. Petrópolis, RJ: Vozes, 1998.

CVETKOVICH, Ann. An archive of feelings: trauma, sexuality and lesbian public cultures. Durham, UK: Duke University Press, 2003.

COMPAGNO, Antoine. O demônio da teoria: literatura e senso comum. Belo Horizonte: Editora UFMG, 2014.

DAVIS, Mike. The monster at our door: the global threat of avian flu. New York: Owl Books, 2006.

DEFOE, Daniel. Um diário do ano da peste. Porto Alegre: Artes e Ofícios, 2014 [1722].

DERRIDA, Jacques. Archive fever: a freudian impression. Chicago, IL: University of Chicago Press, 1995.

DIONísIO, Gustavo. Imagens de pandemia: trauma, luto, arte. Revista Cult, 08 Jul. 2020. Disponível em: <https://revistacult.uol.com.br/home/imagens-de-pandemia-trauma-luto-arte/>. Acesso em: 30 Jul. 2020.

DUARTE, Pedro. Estio do tempo: romantismo e estética moderna. Rio de Janeiro: Editora Zahar, 2011. 
ESCOSTEGUY, Ana Carolina D. No diário dos estudos culturais: o ordinário e o cotidiano como tópicos de pesquisa. Trabalho apresentado ao GT "Comunicação e Sociabilidade", do XVIII Encontro da Compós, na PUC-MG, Belo Horizonte, MG, em Jun. 2009.

FERREIRA, Marieta de Moraes; AMADO, Janaína (Orgs.). Uso \& abusos da história oral. Rio de Janeiro: Editora da FGV, 2011.

FREUD, Sigmund. Neurose, psicose, perversão. Rio de Janeiro: Autêntica, 2016. . Luto e melancolia. São Paulo: Cosac Naify, 2011.

FUKS, Julián. O que a quarentena nos rouba? Inventário de saudades e perdas íntimas. Portal UOL. 23 Maio 2020. Disponível em: <https://www.uol.com.br/ecoa/colunas/julian-fuks/2020/05/23/o-que-a-quarentena-nos-rouba-inventario-de-saudades-e-perdas-intimas.htm>. Acesso em: 30 Jul. 2020.

JEFFERY, Tom. Mass-observation: a short history. Brighton, UK: Mass Observation Archive, 1999.

KISIL, Ian Marino; SILVEIRA, Pedro Telles; NICODEMO, Thiago Lima. Arquivo, memória e big data: uma proposta a partir da Covid-19. Cadernos do Tempo Presente, v. 11, n. 01, p. 90-103, Jan./Jun. 2020.

LEFEBVRE, Henri. Rhythmanalysis: space, time and everyday life. London: Continuum, 2004.

LEJEUNE, Philippe. O guarda-memória. Estudos Históricos, v. 10, n. 19, 1997.

LAPOUJADE, David. Potências do tempo. São Paulo: n-1 edições, 2017.

LUKÁCS, Georg. A teoria do romance. São Paulo: Editora 34, 2007.

PAPACHARISI, Zizi. A private sphere: democracy in a digital age. Cambridge, UK: Polity Press, 2010.

PIGUET, Myriam; MONTEBELLO, Caroline. Covid-19: pour une mémoire ordinaire de l'extraordinaire. Libération, Abr. 2020. Disponível em: <https://www.liberation. $\mathrm{fr} /$ debats/2020/04/25/covid-19-pour-une-memoire-ordinaire-de-I-extraordinaire_1786299>. Acesso em: 30 Jul. 2020.

POLLAK, Michael. Memória, esquecimento e silêncio. Estudos Históricos, v. 2, n. 3, p.3-15, 1989.

RANCIÈRE, Jacques. A partilha do sensível. São Paulo: Editora 34, 2014. 
SELIGMANN-SILVA, Márcio (Org.). História, memória e literatura. Campinas, SP: Editora Unicamp, $2013 a$.

Reflexões sobre a memória, a história e o esquecimento. In: História, memória e literatura. Campinas, SP: Editora Unicamp, 2013b.

O testemunho: entre a ficção e o "real". In: . História, memória e literatura. Campinas, SP: Editora Unicamp, 2013c. . O esplendor das coisas: o diário como memória do presente na Moscou de Walter Benjamin. Revista Escritos, Ano 3, n. 3, p. 161-185, 2009.

WILLIAMS, Raymond. Cultura. São Paulo: Paz e Terra, 2011. . The long revolution. Westport, CT: Greenwood, 1975. 